\title{
Simultaneous evaluation of in vivo glucocorticoid sensitivity and expression of glucocorticoid receptor alpha-isoform in rheumatoid arthritis patients
}

\author{
Avaliação concomitante da sensibilidade in vivo aos \\ glicocorticóides e da expressão da isoforma alfa do receptor \\ de glicocorticóide em pacientes com artrite reumatóide
}

' Rheumatology Discipline, Internal Medicine, Irmandade da Santa Casa de Misericordia de Sao Paulo

${ }^{2}$ Molecular Medicine Laboratory,

Physiology Department

Irmandade Santa Casa de

Misericórdia de Sao Paulo, Faculty of Medical Sciences, Sao Paulo, SP, Brazil

Correspondence to: Murilo R. Melo Rua Maestro Elias Lobo, 126 01433-000 São Paulo SP murilo.melo@fcmscsp.edu.br

Received in May/26/2008 Accepted in Nov/24/2008
Jayme F. Cobra', Murilo R. Melo², Claudia D. C. Faria ${ }^{2}$, Carlos Alberto Longui ${ }^{2}$, Osmar Monte ${ }^{2}$

\section{ABSTRACT}

Objectives: To analyze glucocorticoid (GC) sensitivity using intravenous very low dose dexamethasone suppression test (IV-VLD-DST) in patients with rheumatoid arthritis (RA) and its correlation with glucocorticoid receptor alpha-isoform ( $G R \alpha)$ gene expression. Methods: We evaluated 20 healthy controls and 32 RA patients with Health Assessment Questionnaire (HAQ) and Disease Activity Score 28 joints (DAS) scores and IV-VLD-DST and GR $\alpha$ expression in mononuclear cells. Results: Basal cortisol and the percentage of cortisol reduction after IV-VLD-DST were lower in RA patients than in controls, whereas GR $\alpha$ expression was similar among groups. In the RA group there was an inverse correlation between GR $\alpha$ expression and the percentage of cortisol suppression that was not observed in controls. There was a direct relationship between DAS and GR $\alpha$ expression. Conclusions: Mechanisms involved in GC resistance observed in patients with RA are possibly not at the level of GR $\alpha$ gene expression, since it was similar among groups and GR $\alpha$ increased with disease activity. Arq Bras Endocrinol Metab. 2009;53(1):24-30.

Keywords

Glucocorticoid receptors; rheumatoid arthritis; dexamethasone suppression test

\section{RESUMO}

Objetivos: Determinar a sensibilidade aos glicocorticóides (GC) utilizando teste de supressão com dexametasona em doses muito baixas (IV-VLD-DST) em pacientes com artrite reumatóide (AR) e sua correlação com a expressão gênica da isoforma alfa do receptor glicocorticóide (GR $\alpha$ ). Métodos: Foram avaliados 20 controles saudáveis e 32 pacientes com AR com Health Assessment Questionnaire (HAQ) e Disease Activity Score 28 joints (DAS), IV-VLD-DST e expressão do GR $\alpha$ em células mononucleares. Resultados: Cortisol basal e porcentagem de redução do cortisol após IV-VLD-DST foram menores no grupo AR do que nos controles, enquanto a expressão de GR $\alpha$ foi similar entre eles. No grupo com AR, ocorreu correlação negativa entre a expressão do GR $\alpha$ e a porcentagem de supressão do cortisol, enquanto nos controles não houve correlação. Ocorreu relação direta entre DAS e expressão de GR $\alpha$. Conclusões: Sugerimos que os mecanismos envolvidos na resistência aos GC observada na AR não estejam ao nível da expressão gênica do $G R \alpha$, já que esta é igual entre os grupos e aumenta com a gravidade da doença. Arq Bras Endocrinol Metab. 2009;53(1):24-30.

Descritores

Receptores de glucocorticóides; artrite reumatóide; dexametasona 


\section{INTRODUCTION}

$\mathrm{R}$ heumatoid arthritis (RA) is a chronic, auto-immune, systemic inflammatory disease of unknown etiology. It is characterized by synovial membrane inflammation due to proliferation and infiltration of lymphocytes that determine progressive destruction of cartilage and subchondral bone $(1,2)$. Transcription factors, such as activator protein (AP)- 1 and nuclear factor kappa-B (NF- $\kappa \mathrm{B})$, determine greater expression of pro-inflammatory cytokines, COX-2, growth factors, acute phase proteins and adhesion molecules (3-6). The expression of NF- $\kappa \mathrm{B}$ is increased in RA and seems to be one of the main factors involved in the pathogenesis of the disease $(7,8)$.

Glucocorticoids (GCs) activate the cytosolic glucocorticoid receptor (GR), which translocates to the nucleus to regulate target-gene transcription and determines the reduction of synthesis and release of pro-inflammatory cytokines (9-11), adhesion molecules, COX-2 and proinflammatory transcription factors $\mathrm{NF}-\kappa \mathrm{B}$ and $\mathrm{AP}-1$ protein (12-15). A mutual inhibition of the transcriptional activities between NF- $\kappa \mathrm{B}$ and GR has been observed (16-18), as well as between the AP-1 protein and GR. The anti-inflammatory effects of glucocorticoids are thought to be caused by blocking the activity of the pro-inflammatory transcription factors NF- $\mathrm{BB}$ and AP-1 by direct interaction of a single GR molecule with the DNA-bound NF- $\mathrm{KB}$ or AP-1 heterodimers (11). Variable and skewed concentrations of these transcription factors determine the chronic nature of the inflammatory process observed in RA (7,16-18).

The dramatic response of patients with RA to glucocorticoids, the aggravation of RA after resection of bilateral adrenal glands, the inappropriately normal plasma cortisol levels in patients with RA and the blunted plasma cortisol responses after surgical stress provide evidence that dysregulation of the hypothalamic-pituitary-adrenal axis (HPA) or relative glucocorticoid deficiency might play a part in the development of RA (19).

A number of studies, using semi-quantitative techniques, have demonstrated that the expression of the $G R$ gene is decreased in RA patients in comparison to the healthy population (11,20-22).

In 2004, Melo and cols. described a new technique for absolute quantitation of the alpha isoform of the glucocorticoid receptor $(\mathrm{GR} \alpha)$ using Real-Time PCR (23). Using a similar technique, other authors demonstrated that GR $\alpha$ expression is similar between patients with RA and controls (24).

There is evidence of a dysfunctional hypothalamic-pituitary-adrenal axis in RA patients (25-29), suggestive of resistance to glucocorticoids. This resistance may be related to decreased GR $\alpha$ expression and/or post-receptor abnormalities, such as altered GR $\alpha$ translocation to the nucleus, decreased transactivation and reduced GR $\alpha$ bioactivity secondary to increase of pro-inflammatory transcription factors.

Functional evaluation of the HPA integrity and in vivo sensitivity to GC can be addressed by cortisol suppression tests using dexamethasone (DEX) (30-34). Oral DEX-tests employing low doses allow the identification of the individual spectrum of glucocorticoid sensitivity (32); however, in order to avoid the interference of drug absorption and liver first-passage of DEX, our group recently developed a cortisol suppression test using intravenous dexamethasone in a very low dose $\left(20 \mu \mathrm{g} / \mathrm{m}^{2}\right.$; IV VLD-DST) (33).

The relationship between GR $\alpha$ gene expression and the amplitude of cortisol reduction after DEX can be an important index for the recognition of conditions with hyposensitivity or hypersensitivity with wide applicability in clinical practice.

The present study is the first to determine the individual sensitivity to GCs using the intravenous very low dose DEX suppression test in patients with RA and to correlate this sensitivity with GR $\alpha$ gene expression, using quantitative real-time PCR (qRT-PCR).

\section{PATIENTS AND METHODS}

We studied 32 individuals with RA from the Rheumatology Clinic of the Internal Medicine Department of the Irmandade da Santa Casa de Misericórdia São Paulo, who fulfilled the classification criteria of the American College of Rheumatology and that were not treated with glucocorticoids or tolerated its withdrawal, since HPA should not be suppressed in order to have an informative response during the IV-VLD-DST (35). We also studied 20 healthy control individuals, who were not under steroids or non-steroid anti-inflammatory drugs (NSAIDs) during the last 6 months. The protocol was approved by the Institutional Ethics Committee and all individuals signed a written consent prior to their inclusion in the study protocol.

Control and RA groups were paired to gender, and women corresponded to $15 / 20$ individuals in the control group and 27/32 patients of the RA group. Age was not paired among groups and was lower in the control group (mean 33.7 years; $\mathrm{SD}=10.7$ ) than in RA patients (mean 42.7 years, $S D=9.3$ ). The mean $(S D)$ BMI was $24.6(3.6) \mathrm{kg} / \mathrm{m}^{2}$ in RA patients and $24.5(2.9) \mathrm{kg} / \mathrm{m}^{2}$ in controls. 
Patients with previous use of glucocorticoids were submitted to slow drug reduction regimen in order to be out of any steroid treatment for at least 60 days before undergoing the suppression test. To assure that the HPA was not suppressed, we defined a basal cortisol level of $7 \mu \mathrm{g} / \mathrm{dL}$ as a minimum concentration to proceed with the IV-VLD-DST. Patients with baseline cortisol concentrations lower than $7 \mu \mathrm{g} / \mathrm{dL}$ remained free of GC treatment for an additional 30-day period, before cortisol measurement: persistent basal cortisol levels lower than $7 \mu \mathrm{g} / \mathrm{dL}$ was adopted as an exclusion criterion, as well as endocrine disease, prednisone doses greater than $5 \mathrm{mg} /$ day (or equivalent) in the 6 preceding months, obesity and alcoholism.

Clinical characteristics of the RA group were evaluated before and after medication withdrawal (Table 1 ). The mean (SD) RA duration was 7.5(2.6) years. Only 2/32 patients were negative for Rheumatoid Factor and $4 / 32$ did not present erosions on the $\mathrm{x}$-rays of the hands and feet. Seventeen patients $(53.1 \%)$ used three or more disease-modifying anti-rheumatic drugs (DMARDs), 13 (40.6\%) used 2 DMARDs and 2 (6.3\%) used only one DMARD.

Disease activity was estimated using the Disease Activity Score 28 joints (DAS-28) where variables include erythrocyte sedimentation rate (ESR), number of painful joints and those with synovitis and visual scale for global evaluation of the patient. We applied a Health Assessment Questionnaire (HAQ) with visual scales of pain and the duration of morning rigidity and use of NSAIDs and analgesics were also reported.

The control group was composed of healthy volunteers, graduating students at the Santa Casa de São PauloFaculty of Medical Sciences, paired to the study group in relation to BMI and gender.

\section{VERY LOW DOSE INTRAVENOUS DEXAMETHASONE SUPPRESSION TEST (IV- VLD-DST)}

All patients and controls were submitted to the very low dose $\left(20 \mu \mathrm{g} / \mathrm{m}^{2}\right)$ intravenous dexamethasone suppression test. We recently described how this new test can be used to evaluate individual sensitivity to GC in different age groups (33). Briefly, after a fasting period of 10-12 hours, individuals from both groups received IV dexamethasone disodium phosphate (Decadron ${ }^{\circledR} 2 \mathrm{mg} /$ $\mathrm{mL}$ - Prodome Chemical and Pharmaceutical, Brazil) at a dose of $20 \mu \mathrm{g} / \mathrm{m}^{2}$ BSA in bolus, and 30 minutes of rest Later, a blood sample was taken for cortisol measurement and separation of peripheral mononuclear cells.

The subsequent blood sample collections were performed every 30 minutes up to 150 minutes for cortisol measurement by RIA (BRIDGE, Adaltis, Casalecchio di Remo, Italy).

\section{GR $\propto$ DETERMINATION BY QRT-PCR}

Mononuclear cells were separated from a $20 \mathrm{~mL}$ venous blood sample collected in two $10 \mathrm{~mL}$ tubes containing sodium heparin (Vacutainer, Becton-Dickinson), after addition of $20 \mathrm{~mL}$ of Histopaque ${ }^{\circledR}-1077$ (Sigma, USA) and centrifugation protocol for 30 minutes at $800 \mathrm{~g}$, according to manufacturer's recommendation. Cell viability was verified in a hemocytometer (Neubauer chamber), using the Trypan blue dye (Trypan Blue Solution $0.4 \%$, Sigma, USA).

Total RNA was isolated from cells using guanidinium thiocyanate-chloroform extraction (Trizol, Gibco, USA). After extraction, total RNA was diluted in $40 \mu \mathrm{L}$ of water (DNase/RNase-free water, GIBCO, USA). Complementary DNA (cDNA) was synthesized from l $\mu$ g total RNA using a reverse transcription reaction (TaqMan Reverse Transcription Reagents, Applied Biosystems).

Table 1. Clinical and laboratory data before and after prednisone withdrawal in RA patients.

\begin{tabular}{lcc}
\hline & $\begin{array}{c}\text { Before prednisone withdrawal } \\
\text { Mean (SD) }\end{array}$ & $\begin{array}{c}\text { 60 days after prednisone withdrawal } \\
\text { Mean (SD) }\end{array}$ \\
\hline Number of painful joints & $1.65(1.43)$ & $2.21(2.09)$ \\
\hline Number of joints with synovitis & $6.41(2.77)$ & $6.44(2.86)$ \\
Morning rigidity (minutes) & $40.2(23.81)$ & $51.7(32.76)$ \\
\hline Pain Visual Scale (cm) & $3.8(2.15)$ & $5(1.64)$ \\
Erythrocyte Sedimentation Rate (mm/h) & $30.4(6.65)$ & $31.2(6.53)$ \\
Health Assessment Questionnaire & $1.1(0.65)$ & $1.7(0.67)$ \\
\hline DAS-28 & $4.17(0.86)$ & $4.49(0.82)$ \\
\hline Number of patients with NSAIDs & $18(0.5)$ & $30(0.25)$ \\
\hline
\end{tabular}


GR $\alpha$ expression was determined according to the protocol previously described by our group (23). Briefly, a real-time PCR was performed for $G R \alpha$ and $B C R$ (Breakpoint Cluster Region) as a normalizing gene. Primers and probes were as follows: GR $\alpha$ Sense Primer GAAGGAAACTCCAGCCAGAA; GR $\alpha$ Anti-sense Primer CAGCTAACATCTCGGGGAAT (Product size: 15lbp); GR $\alpha$ Probe 6-FAM-GCTTCCAAACATTTTTGGATAAGACCAT-TAMRA; BCR Sense Primer CCTTCGACGTCAATAACAAGGAT; BCR Anti-Sense Primer CCTGCGATGGCGTTCAC (Product size: 67bp); BCR Probe: 6-FAM-TCCATCTCGCTCATCATCACCGACA-TAMRA.

In each PCR run, we used a standard curve using serial dilutions of cDNA obtained from a standardized Jurkat (E6-1 clone, ATCC) cell culture. PCR conditions were equal for both genes, using TaqMan PCR Core kit (Applied Biosystems, USA). Briefly, IX TaqMan buffer A, $500 \mu \mathrm{M}$ each dNTP, $4.5 \mathrm{mM} \mathrm{MgCl}_{2}, 200 \mathrm{nM}$ of each primer, $100 \mathrm{nM}$ of probe, $0.025 \mathrm{U} / \mu \mathrm{L}$ of AmpliTaq Gold, $5 \mu \mathrm{L}$ of cDNA and water were incubated in a total volume of $25 \mu \mathrm{L}$. Cycle conditions on an ABI 7500 (Applied Biosystems) were: $95^{\circ} \mathrm{C}$ for 10 minutes (AmpliTaq Gold activation) followed by 45 cycles of $95^{\circ} \mathrm{C}$ for 15 seconds (denaturation) and $60^{\circ} \mathrm{C}$ for 90 seconds (annealing and extension). The ratio between $G R \alpha$ and $B C R$ expression represents the number of GR $\alpha$ Expression Units (EU GR $\alpha$ of each sample.

\section{STATISTICAL ANALYSIS}

The comparison between cortisol concentrations from the same individual, before and after DEX suppression test was performed by a paired t-test. The comparison between RA patients and controls in relation to baseline concentrations, lower concentrations and percent of cortisol suppression was performed using the Student- $t$ test or the Mann-Whitney Rank Sum Test, according to data distribution evaluated by the Kolmogorov-Smirnov test. Cortisol concentration at different time points during DEX suppression test was analyzed by KruskalWallis One Way Analysis of Variance on Ranks (ANOVA on Ranks). Correlations between the percentage of cortisol suppression (F\%) and the expression of $G R$ were analyzed using linear regression equations (SigmaStat for Windows, v3.05). Linear regression equations of the standard curves and expression units of GR $\alpha$ (EU GR $\alpha)$ calculations were performed using MS-Excel 2000 for Windows software (Microsoft). A p-value $<0.05$ was considered statistically significant.

\section{RESULTS}

\section{CLINICAL CHARACTERISTICS OF RA PATIENTS}

At the time prednisone was interrupted, 18 patients were receiving $5 \mathrm{mg}$ per day and 11 had been using between $2.5 \mathrm{mg}$ and $5 \mathrm{mg}$ per day. Only 3 patients had not been previously receiving prednisone. There was a minimal but significant difference of $G R$ expression (ANOVA, $\left.\mathrm{p}=0.034, \mathrm{r}^{2}=0,169\right)$ but not of $\mathrm{F} \%$ reduction $(\mathrm{p}=0.165)$ according to previous prednisone dose.

Clinical worsening was observed when patients were clinically evaluated after at least 60 days of prednisone withdrawal. There was an increase in Health Assessment Questionnaire results from 1.1 to 1.7 after two months of GC-free period $(\mathrm{p}<0.001$, paired $\mathrm{t}$-test). The time period of morning rigidity increased from a median of $30 \mathrm{minu}-$ tes to 51.6 minutes $(\mathrm{p}<0.001$, Wilcoxon signed-rank test; mean values are shown in Table 1 ) and the intensity of pain also increased, in visual pain scale (VPS), from mean (SD) values of $3.8 \mathrm{~cm}(2.1)$ to $5 \mathrm{~cm}(1.6)(\mathrm{p}<0.001$, paired $\mathrm{t}$-test), the mean (SD) DAS-28 varied from $4.2(0.9)$ to $4.5(0.8)$ $(\mathrm{p}<0.001$, paired t-test). There was no change in ESR after prednisone discontinuation $(30.4$ to $31.2 \mathrm{~mm} / \mathrm{h}, \mathrm{p}=0.531$, paired t-test). After two months without prednisone, all patients were only using NSAIDs and analgesics.

\section{INTRAVENOUS VERY LOW DOSE DEXAMETHASONE SUPPRESSION TEST (IV-VLD-DST)}

Mean (SD) baseline cortisol concentrations in the RA group was $12.5(3.6) \mu \mathrm{g} / \mathrm{dL}$. A significant reduction was observed when comparing baseline cortisol concentrations with the lowest cortisol concentration obtained after IV-VLD-DST (7.0 [2.2] $\mu \mathrm{g} / \mathrm{dL})(\mathrm{p}<0.001)$. Mean (SD) baseline cortisol concentration in the control group was $19.8(4.4) \mu \mathrm{g} / \mathrm{dL}$, also showing a significant reduction to $6.4(1.8) \mu g / d L(p<0.001)$ after IV-DEX.

When both groups were compared, baseline cortisol concentration was significantly lower in RA patients in comparison to the control group $(\mathrm{p}<0.001)$. However, the lowest concentration obtained from the suppression test was similar between the two groups $(\mathrm{p}=0.287)$. The mean $(\mathrm{SD})$ percentage of cortisol reduction (F\%) after the IV-VLD-DST was significantly lower $(\mathrm{p}<0.001)$ in the RA group: $43.8 \%$ (8.8) in comparison to the control group: $67.6 \%(7.0)$. The $\mathrm{F} \%$ observed for three patients in the RA group who did not receive prednisone previously was similar to the remainder of the group (mean $47.2 \%$ and $43.4 \%$, respectively). 


\section{GR $\alpha$ QUANTITATION BY REAL TIME PCR}

Mean (SD) GR $\alpha$ expression was similar between RA patients (1.2 [0.19] EU GR $\alpha$ ) and control individuals (1.24 [1.7] EU GR $\alpha$; $=0.54)$. GR $\alpha$ expression observed for three patients in the RA group that did not receive prednisone previously was similar to the remainder of the group (mean $1.12 \mathrm{EU}$ and $1.22 \mathrm{EU}$, respectively).

The relationship between $G R \alpha$ expression and the percentage of cortisol suppression is illustrated in Figure 1. In control individuals, although no correlation was observed between GR $\alpha$ expression and the percentage of cortisol suppression, the angular coefficient of the regression line was positive. On the contrary, an inverse correlation was observed between GR $\alpha$ expression and cortisol suppression in the RA group $\left(\mathrm{p}=0.034 ; \mathrm{r}^{2}=0.157\right)$.

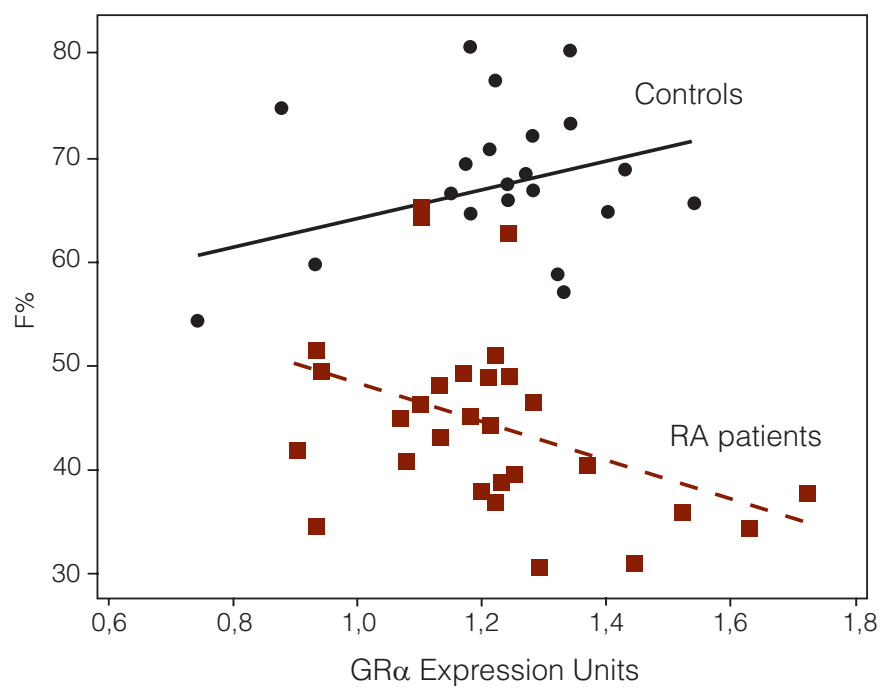

Figure 1. Relationship between GR $\alpha$ expression and percentage of cortisol suppression ( $\mathrm{F} \%$ ) after IV-DEX. There is an inverse relationship of $\mathrm{F} \%$ and $\mathrm{GR} \alpha$ expression in $\mathrm{RA}$ patients ( $\mathrm{F} \%=66.7$ - $18.4 \mathrm{GR} \alpha$; $\mathrm{r} 2=0.157 ; \mathrm{p}=0.034)$; however, in controls there is a non-significant relationship in the opposite direction ( $\mathrm{F} \%=50.9+$ $13.5 \mathrm{GR} \alpha$; $2=0.108 ; \mathrm{p}=0.158)$.

\section{CORRELATION BETWEEN GR $\alpha$ EXPRESSION AND DISEASE ACTIVITY}

A trend of positive correlation was observed between $G R \alpha$ expression and DAS-28 values 60 days after prednisone withdrawal $(\mathrm{p}=0.05 ; G R \alpha(\mathrm{EU})=0.827+0.084$ DAS; $\left.r^{2}=0.135\right)$ and an inverse correlation between GR $\alpha$ expression and the absolute variation of DAS-28 (expressed as $\triangle \mathrm{DAS} ; \mathrm{p}=0.03 ; G R \alpha(\mathrm{EU})=1.27-0.2$ DAS; $\left.r^{2}=0.163\right)$.

\section{DISCUSSION}

Overall, clinical characteristics of RA patients demonstrate that the group is formed by individuals with severe RA with elevated inflammatory potential: more than $93 \%$ of the patients used more than one DMARD, $53 \%$ more than 3 DMARDs, 94\% presented high titers of Rheumatoid Factor and $88 \%$ presented erosions on the radiological exam. This, possibly reflects a severity bias of RA at our Institution, a tertiary care hospital in São Paulo, Brazil. After prednisone withdrawal, there was an increase in disease activity, measured by the DAS28, HAQ and use of NSAIDs. This demonstrates that, despite the use of 2, 3 or more DMARDs, even the additional use of low dose prednisone is able to improve disease control. It was possible to obtain the release of the HPA axis sixty days after prednisone withdrawal, considering as normal the baseline cortisol levels greater than $7 \mu \mathrm{g} / \mathrm{dL}$. Although only three patients were not previously receiving prednisone, there was no difference in GR $\alpha$ expression or F\% reduction after there was no difference in GR > IV-VLD-DST when we compared the three patients who do not received prednisone with those prednisone was withdrawal before the study. This suggests that the HPA axis was not supressed at the time the study was performed.

Intravenous very low dose dexamethasone significantly reduced cortisol concentration and allowed the recognition of individual glucocorticoid sensitivity by identifying a spectrum of cortisol reduction in both RA and control groups. This is the first time this test was used in patients with RA in order to evaluate HPA integrity and to determine GC sensitivity.

Basal cortisol concentration was $58 \%$ higher in the control group in comparison to the RA group, although within reference range. Other studies have found opposite results, with RA patients presenting baseline cortisol concentration similar or greater in comparison to the control group $(36,37)$. The partial cortisol suppression observed in our patients can represent a residual effect consequent to the chronic use of GC. Moreover, several studies demonstrate abnormal response of the HPA to several stress conditions $(10,27,28)$. Straub and cols $(26)$ found an increase in cortisol concentrations and high concentrations of IL- 6 and $\mathrm{TNF} \alpha$ in individuals with active RA not under treatment; however, the increased cortisol concentration was lower than predicted by the observed high levels of cytokines, concluding that the HPA response is inadequate in relation to the elevated inflammatory stimuli. Similar to our findings, Eijsbouts and cols (29) also observed lower cortisol 
concentrations in individuals with RA during insulin tolerance tests, despite increased IL-6 concentration. Despite high HPA stimulatory concentrations of pro-inflammatory cytokines, its activity in RA is still lower than expected.

Accepting that in RA patients there is a HPA dysfunction in response to stressors, the differences between baseline cortisol concentrations in RA patients and control individuals could be related to this abnormal condition. The test itself may cause additional anxiety and stress.

Although cortisol reduction after IV-DEX was significant in both groups, it was less intense in the RA group, possibly representing a partial resistance to the GC negative feedback at the CNS level.

Although an initial hypothesis for this resistance would be a decreased expression of GR, secondary to the homologous down-regulation exerted by exogenous GC upon its own receptor, it was previously described that this mechanism begins 4 hours after the exposure of the GR to GC, with maximum activity between 18 and 24 hours, and with subsequent disappearance 48 hours after reducing the GC to half of its initial dose (37). Therefore, since in our study the patients remained 60 days without exposure to GC, this was a sufficient period to avoid interference in GR expression.

A potential mechanism involved in GC resistance observed in RA patients would be an intrinsic decrease on GR expression. On the other hand, we observed that GR $\alpha$ expression was similar in both RA and control groups. Using more accurate methods, such as qRT-PCR, our findings are comparable to the results described by Onda and cols. (24), demonstrating that GR $\alpha$ of RA patients are similar to controls. This corroborates the hypothesis that after 60 days without prednisone, down-regulation of GR was not the predominant mechanism influencing HPA sensitivity. Additionally, we observed in RA patients that the greater GR $\alpha$ expression, the lower the amplitude of cortisol suppression during IV-DEX (Figure 1).

Furthermore, we observed a direct relationship between disease activity (DAS-28; Disease Activity Score 28 joints) and the level of GR $\alpha$ expression. These two observations suggest a post-receptor resistance mechanism, in which the highly expressed GR $\alpha$ is not enough to reduce the inflammatory activity of the disease, recognized by DAS- 28 and despite its greater expression there is lower (and not higher, as would be expected) in vivo sensibility to DEX.

The inverse correlation between GR $\alpha$ expression and the amplitude of variation in DAS-28, before and after prednisone withdrawal also suggests a resistance related to abnormalities at post-receptor level, in which individuals with higher GRo expression also presented a more significant increase of DAS-28 after prednisone withdrawal.
If the resistance to GC was simply inversely correlated to GR $\alpha$ expression, the increase in disease activity would be more evident in those individuals with lower GR $\alpha$ expression, but this condition was not observed.

Abnormal translocation of the activated GR $\alpha$ to the nucleus, co-inactivation of $G R \alpha$ with $N F-\kappa B$ and AP-1 protein, heterodimerization of $G R \alpha$ with $G R \beta$ and altered expression and/or function of co-activators, could all be together post-receptor interferents increasing the resistance to GC $(16,38-42)$.

Future studies should address the disequilibrium in the

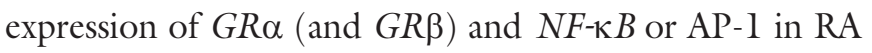
patients as a potential source of a post-receptor resistance mechanism. Therefore, our data support the hypothesis that the resistance mechanisms to GC observed in patients with RA are not secondary to a reduced expression of $G R \alpha$ but rather to alterations at post-receptor level.

Acknowledgements: We thank Fundação ao Amparo à Pesquisa do Estado de São Paulo (Fapesp) (grant \# 04/03208-2) and FAP - Fundo de Amparo à Pesquisa da Faculdade de Ciências Médicas da Santa Casa de São Paulo) (grant \# 03/309) for the financial support.

Disclosure: We declare there are no conflicts of interest in this article.

\section{REFERENCES}

1. Manolios N, Geczy C, Schrieber L. Lymphocyte migration in health and inflammatory rheumatic disease. Semin Arthritis Rheum. 1991;209:339-52.

2. Postigo AA, Garcia-Vicuña R, Diaz-Gonzalez F, Arroyo AG, de Landazuri MO, Chi-Rosso G, et al. Increased binding of synovial T Iymphocytes from rheumatoid arthritis to endothelial-leukocyte adhesion molecule-1 (ELAM-1) and vascular cell adhesion molecule-1 (VCAM-1). J Clin Invest. 1992;89(5):1445-52.

3. Yamasaki S, Kawakami A, Nakashima T, Nakamura H, Kamachi M, Honda S, et al. Importance of NF-kappaB in rheumatoid synovial tissues: in situ NF-kappaB expression and in vitro study using cultured synovial cells. Ann Rheum Dis. 2001;60(7):678-84.

4. Baeuerle PA, Henkel T. Function and activation of NF-kappa B in the immune system. Annu Rev Immunol. 1994;12:141-79.

5. Pan J, McEver RP. Regulation of the human P-selectin promoter by Bcl3 and specific homodimeric members of the NF-kB/Rel family. J Biol Chem. 1995;270(39):23077-83.

6. Wang CY, Mayo MW, Korneluk GR, Goeddel EV, Baldwin Jr AS. NF-kappaB antiapoptosis: induction of TRAF1 and TRAF2 and c-IAP1 and cIAP2 to suppress caspase-8 activation. Science. 1998;281(5383):1680-3.

7. Eggert M, Kluter A, Rusch D, Schmidt KL, Dotzlaw H, Schulz M, et al. Expression analysis of the glucocorticoid receptor and the nuclear factor-kB subunit p50 in lymphocytes from patients with rheumatoid arthritis. J Rheumatol. 2002;29(12):2500-6.

8. Hammaker D, Sweeney S, Firestein GS. Signal transduction networks in rheumatoid arthritis. Ann Rheum Dis. 2003;62 Suppl 2:ii86-9.

9. Northrop JP, Crabtree GR, Mattila PS. Negative regulation of interleukin 2 transcription by the glucocorticoid receptor. J Exp Med 1992;175(5):1235-45. 
10. Chikanza LC, Panayi GS. The effects of hydrocortisone on in vitro lymphocyte proliferation and interleukin-2 and -4 production in corticosteroid sensitive and resistant subjects. Eur J Clin Invest. 1993;23(12):845-50.

11. Eggert M, Schulz M, Neeck G. Molecular mechanisms of glucocorticoid action in rheumatic autoimmune diseases. J Steroid Biocherm Mol Biol. 2001;77(4-5):185-91.

12. Cronstein BN, Kimmel SC, Levin RI, Martiniuk F, Weissmann G. A mechanism for the antiinflammatory effects of corticosteroids: the glucocorticoid receptor regulates leukocyte adhesion to endothelial cells and expression of endothelial-leukocyte adhesion molecule 1 and intercellular adhesion molecule 1. Proc Natl Acad Sci USA. 1992;89(21):9991-5.

13. Gil B, Pajares MA, Mato JM, Alvarez L. Glucocorticoid regulation of hepatic S-adenosylmethionine synthetase gene expression. Endocrinology. 1997;138(3):1251-8.

14. Ray KP, Farrow S, Daly M, Talabot F, Searle N. Induction of the E-selectin promoter by interleukin 1 and tumour necrosis factor alpha, and inhibition by glucocorticoids. Biochem J. 1997;328(Pt 2):707-15.

15. Chang DJ, Ji C, Kim KK, Casinghino S, McCarthy TL, Centrella M. Reduction in transforming growth factor beta receptor I expression and transcription factor CBFa1 on bone cells by glucocorticoid. J Biol Chem. 1998;273(9):4892-6.

16. Ray A, Prefontaine KE. Physical association and functional antagonism between the p65 subunit of transcription factor NF-kappa B and the glucocorticoid receptor. Proc Natl Acad Sci USA. 1994;91(2):752-6.

17. Scheinman RI, Gualberto A, Jewell CM, Cidlowski JA, Baldwin Jr AS. Characterization of mechanisms involved in transrepression of NF-kappa B by activated glucocorticoid receptors. Mol Cell Biol.1995;15(2): 943-53.

18. McKay LI, Cidlowski JA. Cross-talk between nuclear factor-kappa B and the steroid hormone receptors: mechanisms of mutual antagonism. Mol Endocrinol. 1998;12(1):45-56.

19. Lee EB, Kim JY, Lee YJ, Song YW. Glucocorticoid receptor polymorphisms in Korean patients with rheumatoid arthritis. Ann Rheum Dis. 2005;64:503-4.

20. Schlaghecke R, Kornely E, Wollenhaupt J, Specker C. Glucocorticoid receptors in rheumatoid arthritis. Arthritis Rheum. 1992;35(7):740-4.

21. Schlaghecke R, Beuscher D, Kornely E, Specker C. Effects of glucocorticoids in rheumatoid arthritis. Diminished glucocorticoid receptors do not result in glucocorticoid resistance. Arthritis Rheum. 1994;37(8):1127-31.

22. Van Everdingen AA, Huisman AM, Wenting MJ, Van Reesema S, Jacobs JW, Bijlsma JW. Down regulation of glucocorticoid receptors in early-diagnosed rheumatoid arthritis. Clin Exp Rheumatol. 2002;20(4):463-8.

23. Melo MR, Faria CD, Melo KC, Reboucas NA, Longui CA. Real-time PCR quantitation of glucocorticoid receptor alpha isoform. BMC Mol Biol. 2004;5(1):19.

24. Onda K, Rimbara E, Hirano T, Oka K, Abe H, Tahara K, et al. Role of mRNA expression of transcription factors in glucocorticoid sensitivity of peripheral blood mononuclear cells and disease state in rheumatoid arthritis. J Rheumatol. 2004;31(3):464-9.

25. Chikanza IC, Roux-Lombard P, Dayer JM, Panayi GS. Tumour necrosis factor soluble receptors behave as acute phase reactants following surgery in patients with rheumatoid arthritis, chronic osteomyelitis and osteoarthritis. Clin Exp Immunol. 1993;92(1):19-22.

26. Straub RH, Paimela L, Peltomaa R, Schlomerich J, Leirisalo-Repo $\mathrm{M}$. Inadequately low serum levels of steroid hormones in relation to interleukin-6 and tumor necrosis factor in untreated patients with early rheumatoid arthritis and reactive arthritis. Arthritis Rheum. 2002;46(3):654-62.

27. Straub RH, Kittner JM, Heijnen C, Schedlowski M, Schmidt RE, Jacobs $R$. Infusion of epinephrine decreases serum levels of cortisol and 17-hydroxyprogesterone in patients with rheumatoid arthritis. J Rheumatol. 2002;29(8):1659-64.

28. Gutierrez MA, Garcia ME, Rodriguez JA, Mardonez G, Jacobelli S, Rivero $S$ Hypothalamic-pituitary-adrenal axis function in patients with active rheumatoid arthritis: a controlled study using insulin hypoglycemia stress test and prolactin stimulation. J Rheumatol. 1999;26(2):277-81.

29. Eijsbouts AM, van den Hoogen FH, Laan RF, Hermus AR, Sweep CG, van de Putte LB. Hypothalamic-pituitary-adrenal axis activity in patients with rheumatoid arthritis. Clin Exp Rheumatol. 2005;23(5):658-64.

30. Nieman LK. Diagnostic tests for Cushing's syndrome. Ann N Y Acad Sci. 2002;970:112-8.

31. Maguire KP, Schweitzer I, Biddle N, Bridge S, Tiller JW. The dexamethasone suppression test: importance of dexamethasone concentrations. Biol Psychiatry. 1987;22(8):957-67.

32. Longui CA, Giusti MM, Calliari LE, Katiki T, Kochi C, Monte O. Partial glucocorticoid resistance in obese children detected by very low dose dexamethasone suppression test. J Pediatr Endocrinol Metab. 2003;16,1277-82.

33. Faria CDC, Cobra JF, Silva TS, Melo MR, Rocha MN, Hayashi LS, et al. A Very Low Dose Intravenous Dexamethasone Suppression Test as an Index of Glucocorticoid Sensitivity. Horm Res 2008;69:357-62.

34. Yehuda R, Southwick SM, Krystal JH, Bremner D, Charney DS, Mason JW. Enhanced suppression of cortisol following dexamethasone administration in posttraumatic stress disorder. Am J Psychiatry. 1993;150(1):83-6.

35. Arnett FC, Edworthy SM, Bloch DA, McShane DJ, Fries JF, Cooper NS, et al. The American Rheumatism Association 1987 revised criteria for the classification of rheumatoid arthritis. Arthritis Rheum. 1988; 31(3):315-24.

36. Crofford LJ, Kalogeras KT, Mastorakos G, Magiakou MA, Wells J, Kanik KS, et al. Circadian relationships between interleukin (IL)- 6 and hypothalamic-pituitary-adrenal axis hormones: failure of IL-6 to cause sustained hypercortisolism in patients with early untreated rheumatoid arthritis. J Clin Endocrinol Metab. 1997;82(4):1279-83.

37. Boss B, Neeck G. Correlation of IL- 6 with the classical humoral disease activity parameters ESR and CRP and with serum cortisol, reflecting the activity of the HPA axis in active rheumatoid arthritis. Z Rheumatol. 2000;59 Suppl 2:62-4.

38. Okret S, Dong Y, Brönnegard M, Gustafsson JA. Regulation of glucocorticoid receptor expression. Biochimie. 1991;73(1):51-9.

39. Oakley RH, Jewell CM, Yudt MR, Bofetiado DM, Cidlowski JA. The dominant negative activity of the human glucocorticoid receptor beta isoform. Specificity and mechanisms of action. J Biolol Chem. 1999;274(39):27857-66.

40. Webster JC, Oakley RH, Jewell CM, Cidlowski JA. Proinflammatory cytokines regulate human glucocorticoid receptor gene expression and lead to the accumulation of the dominant negative beta isoform: a mechanism for the generation of glucocorticoid resistance. Proc Natl Acad Sci USA. 2001;98(12):6865-70.

41. Neeck G, Klüter A, Dotzlaw H, Eggert M. Involvement of the glucocorticoid receptor in the pathogenesis of rheumatoid arthritis. Ann N Y Acad Sci. 2002;966:491-5.

42. Faria CDC, Longui CA. Molecular aspects of glucocorticoid sensitivity. Arq Bras Endocrinol Metabol. 2006;50(6):983-95. 